УДК 81 '37

DOI 10.23951/1609-624X-2020-2-76-84

\title{
МЕТАФОРИЗАЦИЯ ВКУСОВЫХ ПРИЗНАКОВ В РУССКОМ ЯЗЫКЕ И КАРТИНЕ МИРА
}

\author{
А. А. Полякова ${ }^{1}$, Е. А. Юрина ${ }^{1,2}$ \\ ${ }^{1}$ Национальный исследовательский Томский государственный университет, Томск \\ ${ }^{2}$ Государственный институт русского языка им. А. С. Пушкина, Москва
}

Введение. Представлено когнитивное и семасиологическое исследование метафоризации вкусовых признаков (вкусный, сладкий, кислый, свежий и т. п.), составляющих один из значимых сегментов концептуальной гастрономической метафоры, которую можно представить в виде формулы «Нечто - это Еда».

Материал и методы. Материалом исследования послужили около 200 образных лексических и фразеологических единиц русского языка, метафорически мотивированных 15 прилагательными, которые отражают метафорическое переосмысление свойств продуктов питания. Методология основана на положениях теории образного строя языка. Применяется методика описания образного лексико-семантического поля. Анализ признаковой гастрометафоры включает 4 аспекта: 1) семантический анализ исходных наименований свойств продуктов питания и когнитивный анализ онтологии обозначенных качеств с точки зрения психологии их сенсорного восприятия; 2) структурно-семантический анализ образных языковых средств, репрезентирующих метафоризацию вкусовых свойств, с точки зрения их мотивационных связей в пределах мотивационно-образных парадигм; 3) когнитивный анализ оснований метафорических проекций и описание типовых образных представлений; 4) моделирование фрагмента русской языковой картины мира, представленной системой образных средств языка, отражающих метафоризацию вкусовых свойств продуктов.

Результаты и обсуждение. Прилагательные с семантикой вкусовых свойств продуктов питания служат мотивирующей базой для вторичных номинаций, метафорически называющих широкий круг объектов. Неприятное ощущение от горького вкуса ассоциируется с подавленным психологическим состоянием грусти, печали, обиды. Через метафору кислого вкуса образно характеризуется психологическое состояние человека, связанное с чувством неудовлетворенности, утратой интереса к жизни, вялостью, пассивностью, скукой. Ощущение сладкого вкуса метафорически уподобляется позитивным эмоциям и чувствам: радости, счастью, блаженству. С приторным вкусом метафорически ассоциируется поведение излишне угодливого человека.

Восприятие кислого, пресного, тухлого вкуса и запаха образно ассоциируется со скукой, отсутствием занимательности. Гастрономическое удовольствие от продуктов со сладким и пикантным вкусом метафорически связывается с радостными, волнующими событиями. Насыщенный и резкий вкус пряной пищи, раздражающей вкусовые рецепторы, метафорически проецируется на качества необычных, незаурядных явлений и событий, производящих сильное впечатление своей оригинальностью, яркостью.

Гастрономическое наслаждение, получаемое от сладкой, вкусной пищи, образно связывается с эстетически значимыми речевыми и художественными произведениями. Резкий соленый вкус, а также пряный, пикантный вкусы, раздражающие рецепторы, образно ассоциируются с грубоватыми, пошлыми шутками, словами, выходящими за рамки приличия, речевыми и художественными произведениями, которые оцениваются как непристойные, не вполне приличные.

Высокие вкусовые качества сладких и лакомых блюд, приносящих гастрономическое удовольствие, уподобляются экономической привлекательности ценных и прибыльных объектов торгово-финансовой деятельности. Яркая вкусовая насыщенность пикантных блюд и терпких напитков образно ассоциируется с чувственной, сексуально привлекательной внешностью. Наслаждение от сладкой, лакомой, вкусной пищи метафорически связывается с эстетическим удовольствием, получаемым от созерцания красивого человека. Чрезмерно сладкий вкус образно уподобляется излишне миловидной, с нежными чертами лица внешности.

Заключение. Образные слова и выражения, мотивированные наименованиями вкусовых качеств, метафорически характеризуют объекты и явления различных сфер действительности: внешность, эмоциональное состояние, характер и поведение человека; стиль и содержание речевых и художественных произведений; финансовую значимость объектов экономики; отношение человека к явлениям и событиям жизни.

Ключевые слова: пищевая метафора, признаковая метафора, образная лексика, когнитивная модель.

\section{Введение}

Одной из базовых моделей образной интерпретации мира является метафорическая характеристика объектов действительности по аналогии с продуктами питания, их свойствами, процессами приготовления и поглощения. Каждый национальный язык имеет в своем арсенале лексические и фразеологические средства, обороты речи, транслирующие метафору еды. Русская пищевая метафора неоднократно становилась объектом семантических, когнитивных, лингвокультурологических, сопоставительных исследований в работах А. В. Балдовой, А. С. Бойчук, М. В. Грековой, О. А. Дормидонтовой, Н. А. Живаго, Е. В. Капе- 
люшник, Е. М. Кирсановой, М. Л. Ковшовой, Т. В. Максимовой, Дж. Помаролли, Е. А. Юриной и др. [1-12]. В терминологических обозначениях данного типа концептуальной метафоры авторами используются различные определения: «гастрономическая» $[2,4,9]$, «кулинарная» $[3,5]$, «глюттоническая» [11], «пищевая» $[1,10]$. В наибольшей степени изучена предметная пищевая метафора, основанная на образах блюд, продуктов питания и посуды $[3,7]$. В ряде работ анализируется процессуальная метафора, демонстрирующая переосмысление приготовления и поглощения пищи $[5,12]$. Значительный фрагмент метафоризации пищевой сферы составляет признаковая гастрометафора, которая реализует проекцию различных свойств и качеств продуктов питания на разнообразные явления окружающего мира. Например, безвкусный 'скучный, неинтересный, однообразный' - Опять Лёне показалось, что жизнь его серая и безвкусная. Даже ульбнуться он не мог, даже детям. M. Кучерская; терпкий 'оригинальный, выразительный, привлекающий внимание' - Сравните превращение бесиветной мелодии в более терпкую и приятную с превращением воды в вино в кувшинах Галилейской Каны (В. Ерофеев).

Актуальность изучения признаковой пищевой метафоры определяется малой степенью изученности когнитивной природы признака как такового и феномена признаковой метафоры. Отчасти это объясняется тем, что имя прилагательное как основной грамматический класс слов с признаковой семантикой, в отличие от существительного и глагола, не составляет ядро лексико-грамматической системы и отходит на периферию исследовательского внимания. Однако признаковые метафоры выступают в качестве яркого экспрессивного стилистического средства (метафорический эпитет), используемого для эмоционально-психологического, суггестивного, прагматического, коммуникативного воздействия на адресата речи. В этой связи задача когнитивно-семасиологического исследования признаковой пищевой метафоры представляется весьма актуальной и перспективной.

Объектом изучения в данной статье являются образные лексические и фразеологические единицы русского языка, отражающие метафоризацию вкусовых свойств продуктов питания. Предмет анализа - способы образной характеристики явлений различных концептуальных сфер на основании метафорической интерпретации свойств и качеств продуктов питания.

Цель исследования - определить направления метафоризации образных единиц, мотивированных прилагательными с исходной семантикой вкусовых свойств, выявить основания образных аналогий, описать фрагмент русской языковой карти- ны мира, представленной системой образных средств языка, отражающих признаковую пищевую метафору.

\section{Материал и методы}

Материал исследования составили около 200 образных лексических и фразеологических единиц русского языка, отражающих метафоризацию свойств продуктов питания, которые метафорически мотивированы 15 прилагательными вкусный, горький, кислый, лакомый, пикантный, постный, приторный, пресный, пряный, свежий, сладкий, смачный, соленый, терпкий, тухлый. В их числе языковые метафоры - сладкий 'приятный, доставляющий удовольствие', производные слова с метафорической внутренней формой - кисляй 'вялый, скучный, вечно ноющий человек', контекстуально обусловленные авторские и речевые метафоры - Было так светло, что я различал каждый лист на тополе, каждую мелкую ямочку на дороге, наполненную до краев терпким лунным светом (Ю. Домбровский), устойчивые и авторские сравнительные обороты - будто кислое разжевать 'о недовольном выражении лица', идиомы горький опыт 'пережитые испытания, трудности', авторские образные выражения - И если от продаж бумажных книг деньги хороший писатель получает вполне себе на хлеб и колбасу, то с продажи электронных - фиг без постного масла (Т. Соломатина), пословицы и поговорки - на вкус и цвет товарища нет 'пристрастия и предпочтения разных людей могут сильно отличаться друг от друга'.

Источником контекстного материала послужила текстовая база Национального корпуса русского языка [13].

Методологическую основу работы составила концепция образного строя языка [14], опирающаяся на семасиологическую теорию образности [1518] и когнитивную теорию метафоры [19-21]. Под образным строем языка понимается система образов, закрепленная в узусе и присущая определенному лингвокультурному сообществу $[14$, с. 6$]$. Теория образного строя языка реализует комплексный подход к описанию метафорических и метонимических моделей и средств их языковой репрезентации - образных единиц, объединенных в мотивационно-образные парадигмы (МОП) и образные лексические поля, которые отражают метафоризацию одного концепта или одной концептуальной области $[14$, с. 59-71]. Методика анализа признакового ассоциативно-образного лексико-семантического поля предполагает следующие этапы: 1) выявление максимально полного состава образных единиц, репрезентирующих метафоризацию интегрального признака, а также соответствующих 
им необразных мотивирующих единиц, называющих интегральный признак; 2) исследование лексической семантики, позволяющее распределить языковые средства по ядерной, околоядерной и периферийной зонам поля; 3) группировка образной лексики и фразеологии в мотивационно-образные парадигмы (МОП), в состав которых включаются образные средства, мотивированные одной исходной лексической единицей и демонстрирующие ряд сходных метафорических образов; 4) выявление направлений метафорического переосмысления интегрального признака в пределах каждой МОП, в результате которого вся лексика и фразеология образного поля группируется на основании общности понятийного содержания [14, с. 75-90]. Последний этап связан с выявлением когнитивной структуры типового образного представления, включающей две уподобляемые понятийные сферы (сферу-донор и сферу-мишень), а также свойства, на основании которых происходит уподобление.

В исследовании применялась следующая методика: 1) семантический анализ исходных наименований свойств продуктов питания и когнитивный анализ онтологии обозначенных качеств с точки зрения психологии их сенсорного восприятия; 2) структурно-семантический анализ образных языковых средств, репрезентирующих метафоризацию вкусовых свойств, с точки зрения их мотивационных связей в пределах мотивационно-образных парадигм; 3) когнитивный анализ оснований метафорических проекций и описание типовых образных представлений; 4) моделирование фрагмента русской языковой картины мира, представленной системой образных средств языка, отражающих метафоризацию вкусовых свойств продуктов.

\section{Результаты и обсуждение}

Семантика прилагательных, называющих вкусовые признаки продуктов питания, связана с ощущением вкуса вообще, приятного или неприятного вкуса, основными видами вкуса и комбинациями вкусовых оттенков, качеством продуктов, определяющим степень пригодности в пищу. Выделяются следующие семантические группы:

1) прилагательные, выражающие общую оценку вкусового ощущения с точки зрения приятного, положительно оцениваемого вкуса: вкусный - приятный на вкус, лакомый, смачный - доставляющий вкусовое наслаждение, или неприятного, отрицательно оцениваемого вкуса - невкусный. К этой группе примыкает существительное вкус с широкой семантикой способности к восприятию вкусовых признаков;

2) прилагательные, называющие четыре основных вкуса, выделенных языковым сознанием носи- телей русского языка: горький - имеющий особый неприятный едкий вкус или запах (хины, полыни), сладкий - имеющий приятный вкус (свойственный сахару, меду) или запах, соленый - приправленный солью и имеющий придаваемый ею характерный вкус, кислый - имеющий особы резкий вкус, обусловленный присутствием кислоты в составе продукта;

3) прилагательные, называющие оттенки вкуса с точки зрения более сильного раздражения вкусовых рецепторов: пикантный - острый, пряный на вкус, пряный - острый и ароматный по вкусу и запаху, терпкий - вызывающий вяжущее ощущение во рту, приторный - чрезмерно сладкий; или более слабо ощущаемого вкуса: пресный, постный - не имеющий ярко выраженного вкуса;

4) прилагательные, называющие качества продуктов с точки зрения высокой или низкой степени их пригодности к употреблению в пищу: свежий недавно или только что приготовленный и не потерявший своих естественных хороших качеств,

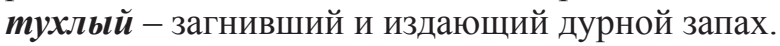

Количественный состав парадигм, вершинами которых являются наименования вкусовых качеств, выглядит следующим образом: прилагательное сладкий мотивирует 83 образных слова и выражения (всласть 'до полного удовлетворения; вдоволь', слащавый 'очень миловидный, с излишне нежными, мягкими чертами лица' и др.), свеж⿻й - 55 образных единиц (свежсо 'современно, необычно, ново', свежий взгляд 'восприятие какой-л. идеи в новом аспекте' и др.), кислый 36 (кислый 'скучный, неинтересный, тоскливый', скисать 'терять бодрость, уверенность; падать духом' и др.), горький - 31 образное слово и выражение (горький 'связанный с разочарованием, досадой, сожалением', горчинка 'недостаток, отсутствие совершенства в чем-л.' и др.), тухлый 29 (протухнуть 'утратить изначально присущие качества, способности', тухлятина 'о чем-л. скучном, неинтересном' и др.), вкус - 18 образных единиц (безвкусица 'отсутствие чувства красивого, изящного, способности эстетической оценки', войти во вкус 'оценив что-л., испытывать от этого удовлетворение, удовольствие' и др.), терпкий 15 (терпкий 'выражающий насмешку, раздражение, критику', терпкость 'волнующая, чувственная привлекательность' и др.), вкусный 10 (вкусный 'выразительный, красочный, яркий', вкуснятина 'что-л. привлекательное, выразительное, вызывающее интерес' и др.), лакомый - 10 (лакомый 'экономически привлекательный, выгодный, приносящий доходы', лакомство 'что-л. интересное, привлекательное, заманчивое' и др.), приторный - 9 образных единиц (приторный 'излишне любезный, ласковый, угодливый’ и др.), $\boldsymbol{n u -}$ 
кантный - 7 образных единиц (пикантность 'то, что возбуждает острый интерес; необычность, сенсационность' и др.), пряный - 7 (пряный 'чувственный, эротичный, связанный с отношениями полов' и др.), пресный - 5 (пресность 'однообразие, отсутствие занимательности, азарта, выразительности' и др.), соленый является мотивирующим для трех образных единиц (соленый 'остроумный, выразительный, но грубоватый, не совсем пристойный' и др.).

Когнитивными основаниями для метафорической характеристики различных объектов действительности по ассоциации со свойствами продуктов питания являются характер и оценка ощущений, возникающих у субъекта поглощения при восприятии пищи: 1) приятный/неприятный вкус; 2) ярко выраженный/слабо выраженный вкус; 3) высокая/ низкая степень пригодности к употреблению. Ощущения от восприятия пищи лежат в основе образной характеристики и оценки таких явлений из сфер-мишеней, как объекты эстетического восприятия, психологические состояния человека, ценностное отношение (удовлетворенность/неудовлетворенность) к каким-л. явлениям, событиям, жизненным ситуациям.

1) Метафоризаиия признаков, связанных с общей оиенкой вкусовых ощущений. Вкусная пища, различные лакомства вызывают положительные эмоции у субъекта поглощения, так как доставляют гастрономическое удовольствие. Поэтому положительные эмоции, чувство удовольствия, получаемые человеком от различных объектов, ситуаций, общения с людьми метафорически связываются с удовольствием, получаемым от вкусной пищи: И я лакомлюсь этой достойной наградой за мои победы (С. Шаргунов). Желание полакомиться вкусным продуктом образно связывается с эмоциональной привязанностью, чувственным влечением к любимому человеку: Примерившись, Варвара поцеловала его во вкусную щеку (Т. Устинова). Экономически привлекательные объекты, выгодные сделки образно ассоциируются с вкусной пищей: Дело в том, что с точки зрения россиянских «пильщиков» и приватизаторов, ядерная отрасль делится на вкусную и невкусную части (Комментарий в чате).

2) Метафоризация основных признаков вкуса. Сладкий вкус пищи оценивается как приятный, а сладкие продукты вызывают у человека положительные эмоции. Физиологически это объясняется тем, что при попадании сладкой пищи в ротовую полость вкусовые рецепторы, кишечник и мозг активируют систему поощрений и запускают выработку дофамина - гормона удовольствия. Этот комплекс ассоциаций лежит в основе метафорической характеристики чувства радости, удовлетво- рения от занятия какой-л. деятельностью, взаимодействия с приятными людьми, наслаждения от счастливой богатой жизни, приятных событий и процессов: Было сладко на душе от этих похвал, слезы подступали (Б. Екимов); Росло ощущение непонимания, несправедливости - в своем отечестве. И никакие награды не могли эту горечь подсластить (Н. Кожевникова). Пристрастие к сладостям ассоциируется с чрезмерным половым влечением, повышенной чувственностью: Наконец доктор (вид сластолюбца, любителя молодых девичьих тел) заметил, что тут находятся совершенно взрослье люди (В. Сидур).

Горький вкус, как правило, не вызывает положительных эмоций у человека. Негативная реакция на горькое служит физиологическим защитным механизмом, поскольку горьким вкусом обладают природные яды и испорченные продукты. Человек, съевший горький продукт, ощущает непроизвольное желание его выплюнуть или запить водой, инстинктивно кривит лицо. Отрицательный чувственный опыт, полученный при поглощении продуктов с горьким вкусом, лежит в основании образной характеристики негативного психоэмоционального состояния человека, его реакций на жизненные трудности, невзгоды: В моей жизни не было более горького опыта, чем Беслан. Я нигде не видел такого количества убитых детей, даже в Ираке («Русский репортер»). Неприятные ощущения, вызванные оставшимся во рту послевкусием от горьких продуктов, образно ассоциируются с печалью, одиночеством, обидой, досадой, горем и другими сильными негативными чувствами, которые мучают человека, доставляют душевный и физический дискомфорт: Бунт был подавлен безжалостно обоими родителями - подавлен до захлебываюшихся слез и такой горечи, такого одиночества, каких Колюня даже не мог вообразить себе (А. Варламов); Я знаю, что тебе на меня плевать, - сказал я горько (В. Пелевин).

Кислый вкус сильно раздражает рецепторы и так же, как и горький, ассоциируется с негативными психоэмоциональными состояниями. Поглощая чрезмерно кислые продукты, едок непроизвольно сжимает челюсти, прикрывает глаза, отчего лицо морщится, кривится и внешне напоминает мимику недовольного, расстроенного человека. Через метафору кислого вкуса в русском языке образно выражаются состояния недовольства, скуки, неудовлетворенности, апатии, которые обычно проявляются через мимику, интонацию, взгляд человека: Делать Нине решительно нечего, и она стала киснуть от скуки (Д. Донщова); Лицо его приняло кисловатое выражение. - Напрасно вы так, не там вы преступников ищете (Е. Сухов). 
Соленый вкус в русской метафорической картине мира образно ассоциируется с переживаниями, житейскими трудностями, невзгодами: По субботам он лежит в изнеможении после недели (уходит в полдевятого, возвращается в одиннадиать, и, видно, солоно ему там приходится - в лаборатории, с плохим немеиким, после трехлетней отвычки) (М. Румер-Зараев).

3) Метафоризация свойств и качеств пищи с ярко/слабо выраженным вкусом. Острый вкус воспринимается человеком не вкусовыми рецепторами, а за счет раздражения болевых окончаний, вызванного химическим веществом капсаицином, которое содержится в острой пище. Наш мозг воспринимает это ощущение как ожог, поэтому понижает болевую чувствительность в ротовой полости, а также начинает активно выделять эндорфин естественное болеутоляющее, которое вызывает у человека ощущение радости. Раздражающий эффект от восприятия острой, пряной, пикантной пищи образно ассоциируется с сильной эмоциональной реакцией на сенсационные события, вызывающие бурный интерес новости, необычные, парадоксальные явления: Высказывания бизнесмена, особенно пикантно прозвучавщие перед Гранпри Германии, вызвали бурю эмочий во всем мире ( «rbcdaily.ru»).

Способность пряной пищи вызывать аппетит метафорически ассоциируется со стремлением удовлетворить чувственное влечение, а наименования качеств острых продуктов образно характеризуют сексуально привлекательную внешность: Одна из женщин ему очень понравилась: лет двадцать восемь, по говору - одесситка, чуть-чуть полновата, что придавало телу острую пикантность, хороша собой (А. Азольский).

Добавляя специи и приправы, возбуждающие вкусовые рецепторы, человек делает ее вкус более разнообразным, такая еда помимо своего естественного приобретает пряный вкус, что метафорически связывается с остроумными, но имеющими скабрезный оттенок высказываниями: Здешние жители горазды на острое, щедро приправленное «перчиком» слово (Ю. Говорухин). Напротив, пресная и постная пища, лишенная ярко выраженного вкуса, не вызывает аппетита, кажется безвкусной, что образно ассоциируется с неинтересными, банальными, однообразными событиями или явлениями, со скучными людьми: Постоянная подруга у меня есть - пресная, положительная, неумело влюбленная, с плохой фигурой, надежная, как весь гражданский флот (А. Пастернак); Нечто унылое, хмурое, постное, меланхолически мутное окружает героев, бодрых, живых, крепких духовными и физическими силами («Российская музыкальная газета»).
Значения образных средств языка, выражающих метафору 'терпкий', демонстрируют неоднозначное отношение к этому вкусу. С одной стороны, он оценивается как неприятный: терпкие продукты раздражают вкусовые рецепторы, оставляют во рту оскомину, вяжущее ощущения. Эти ассоциации лежат в основе метафорической характеристики печальной музыки, неприятных высказываний, мучительных чувств и тягостных событий: Революиия приучила Мандельштама к отъездам, похожим на бегство, к терпким расставаниям (Ю. Нагибин). С другой стороны, терпкость придает продуктам и напиткам необычный, яркий вкус, что ставит их в одну группу с пряными и острыми. Это качество терпких продуктов отразилось в образных наименованиях оригинальных, привлекающих внимание объектов, волнующих ощущений, вызывающих сильные эмоции жизненных событий, привлекательной, чувственной внешности: Как бы я ее потащил на себе, с собой? С ее остротой, холодком, свободой, ясностью, с эдакой женской терпкостью? (Ю. Домбровский).

Метафоризация чрезмерно сладкого вкуса направлена на образную характеристику картинно миловидной внешности: Но это была не та слацавая, конфетная красота, от которой становится приторно, - а нечто иное, из-за чего гибнет женское сердие (T. Тронина); угодливого характера и льстивого поведения человека: Но фальшивость сладостных, елейных речей не всегда удается распознать с ходу (Комментарий 8 чате); а также излишне сентиментальных речевых и художественных произведений, которые оцениваются неодобрительно: «Навстречу жизни» - халтурный роман, беспомощный технически, многие места приторны до омерзения, а в основном - адская скука ("Наш современник»).

4) Метафоризация признаков высокой/низкой степени пригодности к употреблению в пищу. Признак свежести продуктов, недавно добытых или только что приготовленных к употреблению, метафорически выражает идею молодости, здоровья, жизненных сил и умственных способностей человека, еще не утратившего изначально присущих качеств: Можно было с уверенностью ожидать прибытия во Франиию десятков, а потом и сотен тысяч свежих и прекрасно снабжсаемых американских солдат («Эксперт»).

Способность продуктов утрачивать со временем свои положительные вкусовые качества - портиться, прокисать, тухнуть и вследствие этого приобретать характерный неприятный горьковато-кислый вкус и запах - метафорически связывается с негативными изменениями в эмоциональном состоянии и поведении человека: от нейтрального к 
апатии, скуке, недовольству, неудовлетворенности: Да, я страшно люблю разнообразие всюду и во всем, и без него закисаю («Российская музыкальная газета»); А то ты в «Вестях», наверное, тухнешь от скуки. Что может быть интересно настоящееу журналисту в официальном издании? (T. Соколова).

Испорченные (тухлые, прокисшие) продукты, которые невозможно принимать в пищу, образно ассоциируются с бесполезной и бесперспективной деятельностью: - A взрыв этот - брось, тухлое дело, только время потеряешь (В. Громов); неинтересными, скучными произведениями: $B$ конце концов я все-таки выюимаю из себя две странички пошлой кислятины, где вру, вру бесстыдно (Д. Рубина). И напротив, новаторские оригинальные подходы и идеи метафорически связываются с образом свежего продукта: Мысль показалась Юрию свежей и интересной, он даже стал набрасывать в уме статейку на эту тему для заводской многотиражки (И. Грекова).

Явления экономической сферы характеризуют пять образных единиц из МОП «сладкий», «вкусный», «лакомый». Высокие вкусовые качества, приятный вкус сладких и лакомых блюд, приносящих гастрономическое удовольствие, уподобляются экономической привлекательности ценных и прибыльных объектов торгово-финансовой деятельности.

Таким образом, метафора вкусовых свойств продуктов питания образно характеризует внешность, эмоциональное состояние, характер и поведение человека, стиль и содержание речевых и художественных произведений, финансовую значимость объектов экономики, отношение человека к явлениям и событиям жизни.

\section{Заключение}

Проведенное исследование показало, что наибольшее количество образных слов и выражений характеризует поведение человека, характеристику его личности, сложившийся образ взаимодействия с окружающей средой и другими индивидами (68 единиц). Данный фрагмент языковой картины мира представляют единицы МОП «горький», «кислый», «сладкий», «ариторный», «пресный», «тухлый». Неприятное ощущение от горького вкуса метафорически уподобляется грусти, печали, обиде. Ощущение кислого вкуса, который приобретают продукты в результате процессов брожения, приводящих к их непригодности для употребления в пищу, метафорически проецируется на ухудшение психологического состояния человека, связанного с чувством неудовлетворенности, утратой интереса к жизни, вялостью, пассивностью, скукой. Восприятие кислого, пресного и тухлого вкуса и запаха метафорически связывается с поведением скучного, неинтересного человека. Ощущение сладкого вкуса метафорически уподобляется позитивным эмоциям и чувствам: радости, счастью, блаженству. Образ излишне угодливого человека метафорически ассоциируется с приторным вкусом.

События и явления жизни метафорически характеризуют 46 образных единиц, входящих в мотивационно-образные парадигмы «горький», «кислый», «сладкий», «приторный» «пикантный», «пресный», «терпкий», «тухлый», «лакомый», «пряный». Восприятие горького и терпкого вкуса выступает основанием для метафорического переноса на печальные, горестные, тягостные события и жизненные явления. Восприятие кислого, пресного, тухлого вкуса и запаха образно уподобляется скучным жизненным события и процессам, лишенным занимательности. Гастрономическое удовольствие от продуктов со сладким, пикантным и лакомым вкусом метафорически связывается с радостными событиями. Излишне сладкий вкус образно связывается с показным благополучием. Насыщенный и своеобразный вкус пряной пищи, раздражающей вкусовые рецепторы, метафорически проецируется на качества необычных, незаурядных явлений и событий, производящих сильное впечатление своей оригинальностью, яркостью, конфликтные ситуации, нарушающие привычный ход жизни.

Характеристику художественных и речевых произведений выражают 27 образных единиц, входящих в МОП «кислый», «пресный», «тухлый», «сладкий», «вкусный», «терпкий», «пикантный», «соленый». Ощущение кислого, пресного вкуса и тухлого запаха продуктов метафорически проецируется на восприятие скучных, неинтересных речевых и художественных произведений. Гастрономическое наслаждение, получаемое от сладкой, вкусной пищи, образно связывается с эстетически значимыми речевыми и художественными произведениями. Резкий соленый вкус, а также пряный, пикантный вкусы, раздражающие рецепторы, образно ассоциируются с грубоватыми, пошлыми шутками, словами, выходящими за рамки приличия.

Характеристика внешности человека представлена в семантике 11 образными единицами, входящими в МОП «пикантный», «терпкий», «сладкий», «вкусный», «лакомый», «приторный». Яркая вкусовая насыщенность пикантных блюд и терпких напитков образно ассоциируется с чувственной, сексуально привлекательной внешностью. Наслаждение от сладкой, лакомой, вкусной пищи метафорически связывается с эстетическим удовольствием, получаемым от созерцания красивого чело- 
века. Чрезмерно сладкий вкус образно уподобляется излишне миловидной, с нежными чертами лица внешности.

Метафорические контексты иллюстрируют экспрессивно-стилистический эффект использования признаковой гастрометафоры для эмоциональнопсихологического, суггестивного, прагматического коммуникативного воздействия на адресата речи в современных художественных, публицистических текстах и интернет-коммуникации.

Исследование проведено при финансовой поддержке Российского научного фонда. Грант № 18 18-00194 - «Образная система русского языка в полидискурсивном пространстве современных коммуникаиий», 2018-2020 г2.

\section{Список литературы}

1. Балдова А. В. Пищевая метафора как средство выражения оценки и ценностей (на материале образной лексики и фразеологии русского языка) // Вестн. Томского гос. ун-та. 2015. № 396. С. 5-13.

2. Бойчук А. С. Гастрономическая метафора в современном русском языке // Известия Волгоградского гос. пед. ун-та. Серия «Филологические науки». 2010. № 7 (61). С. 75-79.

3. Грекова М. В. Образы посуды в русской метафорической картине мира (когнитивно-дискурсивный и лексикографический аспекты) // Вестн. Томского гос. пед. ун-та (TSPU Bulletin). 2017. Вып. 2 (179). С. 18-24.

4. Дормидонтова О. А. Гастрономическая метафора как средство концептуализации мира (на материале русского и французского языков): автореф. дис. ... канд. филол. наук. Тамбов, 2011. 23 с.

5. Живаго Н. А. Метафоризация образов тепловой обработки пищи в русском языке // Вестн. Томского гос. пед. ун-та (TSPU Bulletin). 2017. Вып. 10 (187). С. 32-38.

6. Капелюшник Е. В. Кулинарный код культуры в семантике образных средств языка: дис. ... канд. филол. наук. Томск, 2012. 199 с.

7. Кирсанова Е. М. Прагматика единиц семантического поля «Пища»: системный и функциональный аспекты: на материале русского и английского языков: автореф. дис. ... канд. филол. наук. М., 2009. 29 с.

8. Ковшова М. Л. Семантика и прагматика фразеологизмов (лингвокультурологический аспект): дис. ... д-ра филол. наук. М., 2009. 654 с.

9. Максимова Т. В. Гастрономическая метафора в разных типах дискурса // Вестник Ленинградского гос. ун-та им. А. С. Пушкина. 2013. T. 1, № 4. C. 176-180.

10. Помаролли Дж. Концепция сопоставительного лингвокультурологического словаря пищевой метафоры на материале русского и итальянского языков // Вестник Томского гос. ун-та. 2018. № 434. С. 40-49.

11. Юрина Е. А. Вкусные метафоры: пищевая традиция в зеркале языковых образов. Кокшетау, 2013. 238 с.

12. Юрина Е. А., Живаго Н. А. Метафоризация поглощения пищи в образном строе русского языка // Вестник Томского гос. ун-та. Филология. 2015. № 3 (35). С. 107-121.

13. Национальный корпус русского языка. 2003-2019. URL: http://www.ruscorpora.ru (дата обращения: 06.08.2019).

14. Юрина Е. А. Образный строй языка. Томск: Изд-во Томского гос. ун-та, 2005. 156 с.

15. Алефиренко Н. Ф. Теория языка. Вводный курс: учеб. пособие для студентов филол. спец. высш. учеб. заведений. М.: Академия, 2004. $368 \mathrm{c}$.

16. Блинова О. И. Явление мотивации слов: Лексикологический аспект. 2-е изд., испр. и доп. М.: ЛИБРОКОМ, 2010. 208 с.

17. Илюхина Н. А. Метафорический образ в семасиологической интерпретации. М.: ФЛИНТА, 2016. 321 с.

18. Скляревская Г. Н. Метафора в системе языка. СПб.: Филологический факультет СПбГУ, 2004. 166 с.

19. Лакоффф Дж., Джонсон М. Метафоры, которыми мы живем // Теория метафоры / под общ. ред. Н. Д. Арутюновой, М. А. Журинской. М.: Прогресc, 1990. С. 387-415.

20. Баранов А. Н., Караулов Ю. Н. Русская политическая метафора: материалы к словарю. М.: Ин-т рус. яз., 1991. 193 с

21. Чудинов А. П. Россия в метафорическом зеркале: когнитивное исследование политической метафоры. Екатеринбург: УргпУ, 2001. $238 \mathrm{c}$.

Полякова Анастасия Андреевна, аспирант, Национальный исследовательский Томский государственный университет (пр. Ленина, 36, Томск, Россия, 634050). E-mail: polyakova3008@mail.ru

Юрина Елена Андреевна, профессор, Национальный исследовательский Томский государственный университет (пр. Ленина, 36, Томск, Россия, 634050), Государственный институт русского языка им. А. С. Пушкина (117485, Москва, ул. Академика Волгина, 6). E-mail: yourina2007@yandex.ru 


\section{METAPHORIZATION OF FOOD TASTE CHARACTERISTICS IN THE RUSSIAN LANGUAGE AND THE WORLD PICTURE}

\section{A. A. Polyakova, E. A. Yurina}

National Research Tomsk State University, Tomsk, Russian Federation

Introduction. The article is devoted to the cognitive and semasiological study of the metaphorization of taste characteristics (delicious, sweet, sour, fresh, etc.) that make up one of the significant segments of the conceptual gastronomic metaphor.

Aim and objectives - to study the directions of metaphorization of figurative units motivated by adjectives with the original semantics of taste properties; to identify the bases of figurative analogies; to describe a fragment of the Russian language picture of the world presented by the system of figurative means of the language reflecting the characteristic food metaphor.

Material and methods. The research material was made up of about 200 figurative lexical and phraseological units of the Russian language, reflecting the metaphorization of the properties of food products, metaphorically motivated by 15 adjectives. The study is based on the theory of the figurative structure of the language, in particular, the method of describing the lexical and semantic field is used.

Results and discussion. Cognitive grounds for metaphorical characterization of various objects of reality are the nature and evaluation of sensations that occur in the subject of eating: 1) pleasant/unpleasant taste, 2) pronounced/ weakly pronounced taste, 3 ) high/low degree of suitability for eating.

Conclusion. The figurative words and expressions, motivated by names of taste qualities, metaphorically characterize objects and phenomena of various spheres of reality: appearance, emotional state, character and behavior of a person; style and content of speech and artistic works; financial significance of economic objects; human attitude to the phenomena and events of life.

Keywords: food metaphor, figurative vocabulary, adjective metaphor, cognitive model.

\section{References}

1. Baldova A. V. Pishchevaya metafora kak sredstvo vyrazheniya otsenki i tsennostey (na materiale obraznoy leksiki i frazeologii russkogo yazyka) [Food metaphor as a means of expressing appreciation and values (based on figurative vocabulary and Russian language phraseology)]. Vestnik Tomskogo gosudarstvennogo universiteta - Tomsk State University Journal, 2015, no. 396, pp. 5-13 (in Russian).

2. Boychuk A. S. Gastronomicheskaya metafora v sovremennom russkom yazyke [Gastronomic metaphor in modern Russian]. Izvestiya Volgogradskogo gosudarvtsvennogo pedagogicheskogo universiteta. Seriya "Filologicheskiye nauki" - Bulletin of the Volgograd State Pedagogical University. Series "Philological Sciences", 2010, no. 7 (61), pp. 75-79 (in Russian).

3. Grekova M. V. Obrazy posudy v russkoy metaforicheskoy kartine mira (kognitivno-diskursivnyy i leksikograficheskiy aspekty) [Images of dishes in the Russian metaphorical picture of the world (cognitive-discursive and lexicographic aspects)]. Vestnik Tomskogo gosudartsvennogo pedagogicheskogo universiteta - TSPU Bulletin, 2017, vol. 2 (179), pp. 18-24 (in Russian).

4. Dormidontova O. A. Gastronomicheskaya metafora kak sredstvo kontseptualizatsii mira (na materiale russkogo i frantsuzskogo yazykov). Avtoref. dis. kand. filol. nauk [Gastronomic metaphor as a means of conceptualizing the world (based on Russian and French languages). Abstract of thesis cand. philol. sci.] Tambov, 2011.23 p. (in Russian).

5. Zhivago N. A. Metaforizatsiya obrazov teplovoy obrabotki pishchi v russkom yazyke [Metaphorization of images of heat treatment of food in Russian]. Vestnik Tomskogo gosudarstvennogo pedagogicheskogo universiteta - TSPU Bulletin, 2017, vol. 10, pp. $32-38$ (in Russian).

6. Kapelyushnik E. V. Kulinarnyy kod kul'tury $v$ semantike obraznykh sredstv yazyka. Dis. kand. filol. nauk [Culinary culture code in the semantics of fi gurative means of language. Diss. of cand. philol. sci.]. Tomsk, 2012. 199 p. (in Russian).

7. Kirsanova E. M. Pragmatika yedinits semanticheskogo polya "Pishcha": sistemnyy i funktsional'nyy aspekty: na materiale russkogo i angliyskogo yazykov. Avtoref. dis. kand. filol. nauk [Pragmatics of the units of the semantic field "Food": systemic and functional aspects: on the material of Russian and English languages. Abstract of thesis cand. philol. sci.]. Moscow, 2009. 29 p. (in Russian).

8. Kovshova M. L. Semantika i pragmatika frazeologizmov (lingvokul'turologicheskiy aspekt). Dis. dokt. filol. nauk [Semantics and pragmatics of phraseological units (linguocultural aspect) Diss. doct. of philol. Sci.]. Moscow, 2009. 654 p. (in Russian).

9. Maksimova T. V. Gastronomicheskaya metafora v raznykh tipakh diskursa [Gastronomic metaphor in different types of discourse]. Vestnik LGU im. A. S. Pushkina - Vestnik of Pushkin Leningrad State University, 2013, no. 4, vol. 1, pp. 176-180 (in Russian).

10. Pomarolli J. Kontseptsiya sopostavitel'nogo lingvokul'turologicheskogo slovarya pishchevoy metafory na materiale russkogo i ital'yanskogo yazykov [The concept of a comparative linguocultural vocabulary of food metaphor based on Russian and Italian languages]. Vestnik Tomskogo gosudarstvennogo universiteta - Tomsk State University Journal, 2018, no. 434, pp. 40-49 (in Russian).

11. Yurina E. A. Vkusnye metafory: pishchevaya traditsiya $v$ zerkale yazykovykh obrazov [Delicious metaphors: food tradition in the mirror of language images]. Kokshetau, 2013. 238 p. (in Russian).

12. Yurina E. A., Zhivago N. A. Metaforizatsiya pogloshcheniya pishchi v obraznom stroye russkogo yazyka [Metaphorization of food absorption in the figurative system of the Russian language]. Vestnik Tomskogo gosudarstvennogo universiteta. Filologiya - Tomsk State University Journal. Philology, 2015, no. 3, pp. 107-121 (in Russian). 
13. Natsional'nyy korpus russkogo yazyka [The Russian National Corpus]. Data of 2003-2019 (in Russian). URL: www.ruscorpora. ru. (accessed 6 August 2019).

14. Yurina E. A. Obraznyy stroy yazyka [Imagery structure of language]. Tomsk, Tomsk State University Publ., 2005. 156 p. (in Russian).

15. Alefirenko N. F. Teoriya yazyka. Vvodnyy kurs: uchebnoye posobiye dlya studentov filologicheskikh spetsial'nostey vysshikh uchebnykh zavedeniy [Theory of language. Introductory course: Textbook for students of philological specialties of higher educational institutions]. Moscow, Akademiya Publ., 2004. 368 p. (in Russian).

16. Blinova O. I. Yavleniye motivatsii slov: Leksikologicheskiy aspect [The phenomenon of motivation of words: Lexicological aspect]. Moscow, Librokom Publ., 2010. 208 p. (in Russian).

17. Ilyukhina N. A. Metaforicheskiy obraz v semasiologicheskoy interpretatsii [Metaphorical image in a semasiological interpretation]. Moscow, Flinta Publ., 2016. 321 p. (in Russian).

18. Sklyarevskaya G. N. Metafora v sisteme yazyka [Metaphor in the language system]. Saint Petersburg, Philological Department of SpbSU Publ., 2014. 166 p. (in Russian).

19. Lakoff G., Johnson M. Metafory, kotorymi my zhivem [Metaphors We Live By]. In: Arutyunova N. D. (ed.) Teoriya metafory [The theory of metaphor]. Moscow, Progress Publ., 1990. Pp. 387-415 (in Russian).

20. Baranov A. N., Karaulov Yu. N. Russkaya politicheskaya metafora: materialy k slovaryu [Russian political metaphor: materials for a dictionary]. Moscow, Institut russkogo yazyka Publ., 1991. 193 p. (in Russian).

21. Chudinov A. P. Rossiya v metaforicheskom zerkale: kognitivnoye issledovaniye politicheskoy metafory [Russia in a metaphorical mirror: a cognitive study of political metaphor]. Ekaterinburg, UrSPU Publ., 2001. 238 p. (in Russian).

Polyakova A. A., National Research Tomsk State University (pr. Lenina, 36, Tomsk, Russian Federation, 634050).

E-mail: polyakova3008@mail.ru

Yurina E. A., National Research Tomsk State University (pr. Lenina, 36, Tomsk, Russian Federation, 634050), Pushkin State Russian Language Institute (ul. Akademika Volgina, 6, Moscow, Russian Federation, 117485). E-mail: yourina2007@yandex. $\mathrm{ru}$ 